УДК 371.315.6:51

Сергій Стріха, кандидат психологічних наук, Національний університет оборони України імені Івана Черняховського, м. Київ

ORCID ID 0000-0002-5937-7748

DOI: $10.33099 / 2617-1775 / 2019-02 / 147-156$

\title{
ТРАНСФОРМАЦІЯ СИСТЕМИ ВІЙСЬКОВОЇ ОСВІТИ УКРАЇНИ НА ШЛЯХУ ДО ДОСЯГНЕННЯ СТАНДАРТІВ НАТО
}

Проаналізовано стан і перспективи розвитку системи військової освіти Украӥни з урахуванням курсу Украйни на інтеграцію в європейський $і$ євроатлантичний політичний, економічний, безпековий, правовий простір. Головним трендом сучасних змін у системі військової освіти України є наближення ї̈ параметрів до рівня найбільш розвинутих у військовому відношенні краӥн Північноатлантичного альянсу. Процес та результати реформування вітчизняної системи вищої військової освіти базуються на співробітництві з іноземними військовими навчальними закладами, вивченні їх досвіду, впровадженні кращих методик в прочес підготовки військових фахівиів для Збройних Сил України з урахуванням національних здобутків.

Ключові слова: оборонна реформа; військова освіта; рівні військової освіти.

Постановка проблеми. Система військової освіти - важлива складова сектору безпеки і оборони України, яка забезпечує Збройні Сили та інші військові формування держави підготовленими офіцерами і сержантами. Варто зазначити, що вона інтегрована у загальнодержавну систему освіти i на сьогодні має у своєму складі університети, академії, військові інститути (в тому числі у складі цивільних університетів), військові коледжі, факультети i кафедри військової підготовки, а також Київський військовий ліцей, низку ліцеїв 3 посиленою військово-фізичною підготовкою.

Основним продуктом системи військової освіти є підготовлені військові кадри для Збройних Сил та інших військових формувань України. Від якості цієї підготовки прямо залежить здатність сил оборони України, а відтак i сектору безпеки і оборони держави в цілому до протистояння зовнішній збройній агресії.

Військову освіту ми сьогодні розглядаємо за двома основними аспектами:

отримання фундаментальних знань і навичок у навчальному закладі;

розвиток i закріплення цих знань i навичок у процесі виконання функціональних обов'язків на посаді у військах через систему курсової підготовки перед призначенням на нові посади.

Система військової освіти в Україні перебуває нині в стані глибоких перетворень відповідно до визначених законодавством України потреб інтеграції України в європейський політичний, економічний, безпековий, правовий простір, набуття членства в Свропейському Союзі та в Організації Північноатлантичного договору [1]. Важливим чинником таких перетворень $\epsilon$ також досвід участі Збройних Сил та інших військових формувань України в 
обороні східних рубежів держави від збройної агресії з боку Російської Федерації.

Аналіз останніх досліджень і публікацій. На виконання рішення Колегії Міністерства оборони України 2017 року щодо удосконалення системи військової освіти і приведення змісту навчання до потреб Збройних Сил 3 максимальним наближенням до стандартів підготовки, що застосовуються в НАТО, у Міністерстві оборони України проведено низку заходів. Фундаментальною основою змін стало приведення відповідних нормативних актів Міністерства оборони України до вимог законів України “Про освіту” [2], "Про вищу освіту" [3], "Про наукову та науково-технічну діяльність" [4] згідно 3 сучасними потребами Збройних Сил України та євроатлантичними стандартами якості підготовки військовослужбовців.

Мета статті. Основною метою статті $\epsilon$ аналіз стану і перспектив розвитку системи військової освіти України на шляху до досягнення стандартів НАТО.

Стандарти НАТО в сфері військової освіти як уособлення високої якості підготовки військових фахівців. Аналіз систем професійної військової освіти країн - членів НАТО показує, що при зовнішній схожості вони мають низку суттєвих відмінностей щодо поєднання професійної військової підготовки та освіти, термінів здобуття освіти або проходження підготовки.

Терміни здобуття освіти у навчальних закладах країн - членів НАТО відповідають вимогам щодо здобуття освітніх рівнів (“бакалавр”, “магістр”) i складають: на тактичному рівні - $3-3,5$ роки; на оперативному рівні - від 10 місяців до одного року; на стратегічному рівні - від 5 місяців до двох років.

Терміни та зміст підготовки (підвищення кваліфікації та професійного рівня) визначаються виходячи із напрямів, мети, змісту цієї підготовки (курсів, факультативів, тощо).

У США створено систему професійної військової освіти, яка поєднана із професійною підготовкою. У більшості країн - членів НАТО переважає професійна військова підготовка, а не військова освіта, що обумовлено малою чисельністю збройних сил та невеликим державним замовленням. Однак спостерігається тенденція до впровадження магістерських програм на оперативному рівні (Балтійський оборонний коледж, Коледж НАТО в Римі), що свідчить про розуміння необхідності поглиблення навченості та освіченості офіцерських кадрів, починаючи з бригадної ланки.

Системи військової освіти країн - членів НАТО (окрім США) імплементовані у національні системи освіти, базуються на вимогах Болонського процесу та регулюються законодавчими або відомчими актами своїх країн в галузі освіти і науки.

Як освітні програми, так i програми професійного підвищення кваліфікації військовослужбовців у європейських країнах - членах НАТО побудовані на європейській кредитно-трансферній системі (ECTS) і мають такі основні ознаки:

трьохступенева система вищої освіти;

європейський додаток до диплому бакалавра і магістра; 
кредити ECTS в якості одиниць обліку трудомісткості навчальної роботи; модульна система навчання;

єдині європейські оцінки;

комплексне управління і моніторинг якості вищої освіти.

Україна приєдналася до європейського інтеграційного процесу в галузі вищої освіти (“Болонського процесу”) і стала частиною європейського освітнього та наукового простору. Це повною мірою стосується і військової освіти. Але за нинішніх умов важливим є впровадження у систему військової освіти норм і правил, які отримали назву так званих стандартів НАТО.

Слід визнати, що поняття “стандарти НАТО" стосовно сфери військової освіти є досить розмитим, тому можна говорити як про введення у систему військової освіти України стандартів НАТО, так і про досягнення рівня підготовки військових фахівців найбільш боєздатних армій країн Альянсу.

Основні результати реалізації рішення Колегії Міністерства оборони України 2019 року з питань удосконалення військової освіти. Зокрема, внесено необхідні зміни до законодавчих та нормативних документів щодо збільшення повноважень Міністерства оборони України в питаннях організації навчальновиховного процесу, організації вступної кампанії, вирішення кадрових питань тощо.

Сформовано нові вищі військові навчальні заклади та військові кафедри підготовки офіцерів запасу. У військових навчальних закладах (ВН3) проведені необхідні організаційні зміни та переатестація наукових та науковопедагогічних кадрів.

Перероблені навчальні програми підготовки з перерозподілом бюджету часу на користь практичної підготовки, внесені зміни до навчально-методичних матеріалів щодо врахування досвіду антитерористичної операції (операції Об’єднаних сил) на сході України.

Введено у практику широке залучення до проведення навчальних занять зі слухачами (курсантами) та на курсах підвищення кваліфікації представників замовників, провідних фахівців Міністерства оборони України, Проектного офісу реформ Міністерства оборони України, волонтерів, фахівців інших силових структур сектору безпеки та оборони держави, а також міжнародних організацій. Це дуже важливо 3 огляду на тимчасовий дефіцит високо підготовлених науково-педагогічних кадрів 3 відповідним практичним досвідом.

Планомірно впроваджуються євроатлантичні технології і процедури в освітньому процесі.

В інтересах розвитку професійних компетентностей офіцерів (курсантів) розгорнуто роботу з опанування ними системами імітаційного моделювання бойових дій військ (сил), автоматизованими системами управління та іншими новітніми інформаційними технологіями.

Зокрема, з метою підвищення ефективності проведення навчальних занять активно використовуються системи імітаційного моделювання, які функціонують в Національному університеті оборони України імені Івана 
Черняховського, м. Київ (НУОУ), в центрі імітаційного моделювання Національної академії Сухопутних військ імені Петра Сагайдачного та в Міжнародному центрі миротворчості і безпеки (структурному підрозділі Академіï). Для цього використовується сучасне програмне забезпечення (Follow Me, VBS-3, J-CATS та інші). На практичних заняттях по вивченню дисциплін “Тактика" та "Управління діями підрозділів" широко використовується система MILES (Multiple Integrated Laser Engagement System), яка призначена для імітації умов реального бою в тактичній підготовці.

Інтенсифіковано розвиток дистанційного навчання як перспективного напряму удосконалення освітнього процесу. В НУОУ у співпраці з академією оборони Норвегії та Центром Джефферсона обладнано клас дистанційного навчання (27 робочих спеціалізованих станцій), закуплено додаткове обладнання для розроблення навчальних курсів. Закуплено та налаштовано сервер для розміщення центрального репозиторію необхідних інформаційних ресурсів. Оновлено програмне забезпечення платформи дистанційного навчання MOODLE. У 2020 році передбачається введення в дію у тестовому режимі серверу дистанційного навчання з доступом до ресурсів через Інтернет. Це дасть змогу охопити навчанням широке коло військових фахівців різного рівня, як в процесі здобуття вищої військової освіти, так і в інтересах професійної військової підготовки та підвищення кваліфікації.

3 метою удосконалення дистанційного навчання відбувається розширення можливостей електронної бібліотеки НУОУ як цілісного комплексу з надання дистанційних освітніх послуг. Крім того, слухачам НУОУ надано можливість користуватися послугами Української науково-освітньої телекомунікаційної мережі УРАН (ця мережа забезпечує користування низкою інформаційних сервісів, у тому числі доступ до консорціуму електронних бібліотек е-VERUM). На сьогодні членами Асоціації УРАН $є$ вже понад 80 українських навчальних закладів та наукових установ.

Розширено систему курсової підготовки за напрямами:

стратегічні комунікації;

демократичний цивільний контроль над воєнною організацією держави;

оперативне планування за стандартами НАТО;

основи теорії лідерства за стандартами НАТО;

основи цивільно-військового співробітництва (CIMIC);

оборонне планування на основі спроможностей;

розбудова доброчесності, прозорості і зниження корупційних ризиків.

Пілотний курс за зазначеними напрямами проведено в НУОУ у лютому 2018 року. Викладання на курсі здійснюється викладачами та науковцями НУОУ, фахівцями Департаменту воєнної політики, стратегічного планування та міжнародного співробітництва Міністерства оборони України, спеціалістами Великої Британії та США. Проведенню курсу передувала підготовка визначеного складу науково-педагогічних працівників НУОУ на спеціальних заняттях, які були організовані в університеті за участі фахівців США та Великої Британії. 
Україна 32012 року бере участь у програмі HATO Defence Education Enhancement Program (DEEP), яка допомагає країнам-партнерам у розвитку та реформуванні системи військової освіти. Основна увага приділяється питанням опрацювання програм певних навчальних дисциплін та удосконаленню методики їх викладання у визначених вищих військових навчальних закладах.

В рамках підвищення професійної кваліфікації за програмою DEEP фахівці Національного університету оборони України імені Івана Черняховського, м. Київ пройшли підготовку:

3 питань виховання доброчесності, запобігання та попередження корупції для посадовців високого рангу (Академія оборони Великобританії, м. Шрівенгем);

з питань Спільної політики безпеки та оборони Свропейського Союзу (м. Кишинів, Республіка Молдова);

3 вивчення стандартів НАТО - стажування в Школі НАТО (м. Обераммергау, ФРН).

Робота за програмою DEEP-Ukraine передбачає триступеневий цикл розроблення кожного курсу: перший етап - проведення курсу інструкторами країн-партнерів для передачі досвіду фахівцям ВН3, другий етап - проведення курсу підготовленими фахівцями ВНЗ в присутності експертів НАТО та країнпартнерів, третій етап - самостійне проведення фахівцями ВНЗ курсів за оновленою тематикою.

У рамках програми DEEP ряд керівників вищих військових навчальних закладів України здійснили поїздки до країн Альянсу для вивчення досвіду навчання і підготовки військових кадрів з метою використання їх досвіду в ході подальшого удосконалення системи військової освіти України.

Курсанти ВНЗ, а також слухачі курсів перепідготовки та підвищення кваліфікації (у перспективі зазначені курси будуть трансформовані у школу менеджменту i школу лідерства) вивчають євроатлантичні процедури прийняття рішень та управління військовими підрозділами на навчальних дисциплінах "Тактика" та "Управління діями підрозділів", “Військова топографія", “Основи військового управління”.

У рамках навчальної дисципліни "Військова топографія" курсанти вивчають порядок використання топографічних карт країн НАТО. 3 грудня 2017 року у військових навчальних закладах України здійснено перехід на використання умовних позначень НАТО під час розроблення графічних оперативних та бойових документів. Запроваджено використання стандарту НАТО АРР - щодо оформлення таких документів.

Впроваджено національний стандарт графічних умовних позначень 3 використанням практики армій країн НАТО (наказ начальника Генерального штабу - Головнокомандувача Збройних Сил України від 25 квітня 2018 року № 170 "Про затвердження Порядку оформлення оперативних (бойових) документів").

Важливим питанням для Збройних Сил сьогодні є підготовка сержантів 3 використанням досвіду НАТО. Перехід до заміщення сержантами первинних 
посад офіцерського складу потребує змін у підходах до комплектування посад зазначеною категорією військовослужбовців, організації навчального процесу відповідних ВНЗ, підготовки нової категорії викладачів - сержантівінструкторів за стандартами НАТО та вирішення блоку супутніх соціальних питань.

Підготовка військовослужбовців військової служби за контрактом на посади сержантського (старшинського) складу здійснюється відповідно до Закону України "Про вищу освіту" за освітньо-кваліфікаційним рівнем “молодший спеціаліст" протягом 2,5 років.

На теперішній час таку підготовку за 15 спеціальностями та 27 спеціалізаціями здійснюють:

військовий коледж сержантського складу Харківського національного університету Повітряних Сил імені Івана Кожедуба;

військовий коледж сержантського складу Національної академії сухопутних військ імені гетьмана Петра Сагайдачного;

військовий коледж сержантського складу Військового інституту телекомунікацій та інформатизації;

відділення військової підготовки Морехідного коледжу технічного флоту Національного університету “Одеська морська академія".

Таким чином, на виконання рішення проведеної у травні 2017 року Колегії Міністерства оборони України, триває масштабна робота 3 впровадження досвіду країн - членів НАТО в процес підготовки військових фахівців для Збройних Сил України.

Висновки та перспективи подальших досліджень:

1. Характерною відмінною ознакою функціонування системи військової освіти на сучасному етапі $\epsilon$ те, що вона виступає водночас як об' єктом, так і суб'єктом реформування Збройних Сил України та сил оборони в цілому. Саме висока якість підготовки військових кадрів $\epsilon$ важливою умовою своєчасності, повноти та ефективності виконання заходів оборонної реформи в Україні.

2. Найбільш значущими заходами наближення системи військової освіти України до євроатлантичних стандартів можна вважати:

перехід на трьохступеневу систему освіти (на тактичному, оперативному та стратегічному рівнях);

запровадження "школи оборонного менеджменту" та "школи лідерства" як складових професіоналізації освіти;

перегляд кваліфікаційних вимог та штатно-посадових категорій до військових посад офіцерського складу з урахуванням освітніх ступенів та рівнів військової освіти;

перегляд змісту освіти та фахової підготовки, впровадження в освітній процес процедур та стандартів НАТО;

рішуче удосконалення підготовки сержантів.

Перспективи розвитку системи військової освіти в Україні на шляху до досягнення стандартів НАТО. Комітет реформ Міністерства оборони України та Генерального штабу Збройних Сил України працює над підвищенням 
ефективності та оптимізації діяльності оборонного відомства, у тому числі у сфері військової освіти. Слід нагадати, що підкомітетом професіоналізації Збройних Сил України та створення військового резерву розроблено "План дій щодо впровадження оборонної реформи у сфері військової освіти та підготовки кадрів у Міністерстві оборони та Збройних Силах України у 2016 - 2020 роках". Цей документ можна вважати Дорожньою картою оборонної реформи у сфері військової освіти та підготовки кадрів.

В основу подальшого реформування системи військової освіти покладені такі напрями:

законодавче і нормативне врегулювання питань підготовки військових фахівців, адаптацію нормативно-правової бази Міністерства оборони України у галузі військової освіти до вимог законодавства держави з урахуванням досвіду проведення антитерористичної операції та операції Об'єднаних сил;

підвищення якості та приведення змісту і технологій навчання військових фахівців у відповідність до сучасних завдань Збройних Сил України та вимог щодо їх підготовки з максимальним використанням досвіду антитерористичної операції та передових методик підготовки армій країн-членів НАТО, впровадження технологій дистанційного навчання;

подальшу оптимізацію мережі вищих військових навчальних закладів та військових навчальних підрозділів закладів вищої освіти (ВВНЗ та ВНП ЗВО), наукових закладів і установ, їх організаційно-штатних структур, поліпшення підготовки науково-педагогічних кадрів, удосконалення механізму ротації науково-педагогічних працівників;

удосконалення системи відбору та підготовки кандидатів на вступ до ВВНЗ та ВНП ЗВО та ії планомірний розвиток;

підвищення якості професійної підготовки у всіх ланках військового управління, військах (силах) та в системі підвищення кваліфікації офіцерських кадрів, державних службовців та працівників Збройних Сил України;

формування і планомірне укріплення системи професійної підготовки сержантів як важливої сучасної категорії військових кадрів;

постійне оновлення та удосконалення матеріально-технічної бази ВВН3 та ВНП ЗВО;

розвиток міжнародної співпраці і міжнародної кооперації у сфері військової освіти 3 метою реалізації стратегічного курсу держави на європейську інтеграцію та євроатлантичне партнерство.

Рішенням Міністра оборони від 5 липня 2018 року № 7530/3/3 визначено ряд нових завдань щодо удосконалення системи вищої військової освіти в Україні, у тому числі:

перехід на більш сумісну з країнами НАТО трьохступеневу систему рівнів військової освіти (тактичний, оперативний та стратегічний рівні);

запровадження діяльності “школи оборонного менеджменту” та “школи лідерства" як складових професіоналізації освіти; 
перегляд кваліфікаційних вимог та штатно-посадових категорій до військових посад офіцерського складу щодо здобуття освітніх ступенів (“бакалавр”, “магістр”) та рівнів військової освіти;

опрацювання механізмів мотивації на здобуття офіцерами освітніх (освітньо-наукових, наукових) ступенів на всіх рівнях військової освіти;

перегляд змісту освіти та фахової підготовки, більш наполегливе впровадження в освітній процес процедур та стандартів НАТО.

На виконання зазначеного рішення у Міністерстві оборони України за участю керівного складу ВНЗ напрацьовані конкретні пропозиції, які $\epsilon$ предметом поступового впровадження в практичну діяльність органів військового управління та керівництва ВНЗ. Основний зміст та терміни реалізації пропозицій відповідають "Переліку основних заходів досягнення цілей партнерства в Міністерстві оборони України та Збройних Силах України на 2016 - 2020 роки", затвердженому Міністром оборони України від 16 червня 2016 року.

\section{ЛІТЕРАТУРА}

1. Закон України "Про національну безпеку України" // [Електронний ресурс]. Режим доступу: http://zakon0.rada.gov.ua/laws/show/2469-19.

2. Закон України "Про освіту" // [Електронний ресурс]. - Режим доступу: http://zakon0.rada.gov.ua/laws/show/2145-19.

3. Закон України "Про вищу освіту" // "Голос України", 6 серпня 2014 року // [Електронний ресурс]. - Режим доступу: http://zakon0.rada.gov.ua/laws/show/1556-18.

4. Закон України "Про наукову та науково-технічну діяльність" // [Електронний pecypc]. - Режим доступу: http://zakon0.rada.gov.ua/laws/show/848-19.

5. Постанова Кабінету Міністрів України від 15 грудня 1997 року № 1410 “Про створення єдиної системи військової освіти" // [Електронний ресурс]. - Режим доступу: http://zakon0.rada.gov.ua/laws/show/1410-97-\%D0\%BF.

6. Постанова Кабінету Міністрів України від 23 листопада 2011 року № 1341 “Про затвердження Національної рамки кваліфікацій” // [Електронний ресурс]. - Режим доступу: http://zakon2.rada.gov.ua/laws/show/1341-2011-\%D0\%BF/paran12\#n12.

7. Великий тлумачний словник сучасної української мови (з дод. і допов.) // Уклад. i голов. ред. В.Т. Бусел. - К.; Ірпінь: ВТФ “Перун”, 2005. - 1728 с.

\section{REFERENCES}

1. Zakon Ukrainy "O natsional'noy bezopasnosti Ukrainy" [The Law of Ukraine]. // [Elektronnyy resurs]. - Rezhim dostupa: http://zakon0.rada.gov.ua/laws/show/2469-19 (in Ukrainian).

2. Zakon Ukrainy "Ob obrazovanii" [The Law of Ukraine "On Education"]. // [Elektronnyy resurs]. - Rezhim dostupa: http://zakon0.rada.gov.ua/laws/show/2145-19 (in Ukrainian).

3. Zakon Ukrainy "O vysshem obrazovanii" [The Law of Ukraine "On Higher Education"]. // "Golos Ukrainy", 6 avgusta 2014 goda // [Elektronnyy resurs]. - Rezhim dostupa: http://zakon0.rada.gov.ua/laws/show/1556-18 (in Ukrainian).

4. Zakon Ukrainy "O nauchnoy i nauchno-tekhnicheskoy deyatel'nosti" [The Law of Ukraine]. // [Elektronnyy resurs]. - Rezhim dostupa: http://zakon0.rada.gov.ua/laws/show/848-19 (in Ukrainian).

5. Postanovleniye Kabineta Ministrov Ukrainy ot 15 dekabrya 1997 goda № 1410 "O sozdanii yedinoy sistemy voyennogo obrazovaniya" // [Elektronnyy resurs]. - Rezhim dostupa: http://zakon0.rada.gov.ua/laws/show/1410-97-\%D0\%BF (in Ukrainian). 
6. Postanovleniye Kabineta Ministrov Ukrainy ot 23 noyabrya 2011 goda № 1341 "Ob utverzhdenii Natsional'noy ramki kvalifikatsiy" // [Elektronnyy resurs]. - Rezhim dostupa: http://zakon2.rada.gov.ua/laws/show/1341-2011-\%D0\%BF/paran12\#n12 (in Ukrainian).

7. Busel V.T. (2005). Bol'shoy tolkovyy slovar' sovremennogo ukrainskogo yazyka [Big Ukrainian explanatory dictionary]. (s dop. i pererab.) // Sost. i glav. red. V.T. Busel. - K.; Irpen': VTF "Perun". - 1728 s. (in Ukrainian).

\section{РЕЗЮМЕ}

Сергей Стриха,

кандидат психологических наук, Национальный университет обороны Украины имени Ивана Черняховского, г. Киев

\section{Трансформация системы военного образования украины на пути к достижению стандартов НАТО}

Резюме. Проанализировано состояние и перспективы развития системы военного образования Украины с учетом курса Украины на интеграцию в европейское $u$ евроатлантическое политическое, экономическое, безопасное, правовое пространство. Главным трендом современных изменений в системе военного образования Украины является приближение её параметров до уровня наиболее развитых в военном отношении стран Североатлантического альянса. Процесс и результаты реформирования отечественной системы выстего военного образования базируются на сотрудничестве $c$ иностранными военными учебными заведениями, изучении их опыта, внедрении лучших методик в процесс подготовки военных специалистов для Вооруженных Сил Украины с учетом национальных достижений.

Ключевые слова: военная реформа; военное образование; уровни военного образования.

\section{SUMMARY}

Serhii Strikha, Candidate of psychological sciences, National Defence University of Ukraine named after Ivan Chernyakhovskyi, c. Kyiv

\section{Transformation of the ukrainian military education system on the way to achieve NATO standards}

Introduction. Formulation of the problem. The military education system is an important component of the security and defense sector of Ukraine, which provides the Armed Forces and other military units of the state with trained officers and sergeants. It is worth noting that it is integrated into the national education system and today includes universities, academies, military institutes (including civil universities), military colleges, faculties and departments of military training, as well as the Kyiv Military Lyceum, a number of lyceums with enhanced military physical training.

Purpose of the article. The main goal of the article is to analyze the state and prospects of the development of the military education system of Ukraine on the way to achieving NATO standards.

Methods. The main product of the military education system is trained military personnel for the Armed Forces and other military units of Ukraine. The ability of the defense forces of Ukraine, and then the security sector and the defense of the state as a whole, to confront external armed aggression directly depends on the quality of this training. 
The military education system in Ukraine is now in a state of profound transformation in accordance with the specific legislation of Ukraine, the needs of Ukraine's integration into the European political, economic, safe, legal space, membership in the European Union and the North Atlantic Treaty Organization. An important factor in such transformations is also the experience of the participation of the Armed Forces and other military units of Ukraine in the defense of the eastern borders of the state from armed aggression by the Russian Federation.

Results. Ukraine joined the European integration process in the field of higher education (the Bologna Process) and became part of the European educational and scientific space. This fully applies to military education. But in the current conditions, it is important to introduce norms and rules into the military education system, which are called the so-called NATO standards.

It should be recognized that the concept of "NATO standards" in relation to the field of military education is quite vague, therefore we can talk about the introduction of NATO standards in the military education system of Ukraine, and about the achievement of the level of training of military specialists of the most combat-ready armies of the Alliance countries.

Originality. The state and prospects of development of the military education system of Ukraine are analyzed taking into account the course of Ukraine towards integration into the European and Euro-Atlantic political, economic, safe, legal space. The main trend of modern changes in the military education system of Ukraine is the approximation of its parameters to the level of the most developed militarily countries of the North Atlantic Alliance. The process and results of reforming the domestic system of higher military education are based on cooperation with foreign military educational institutions, the study of their experience, the introduction of best practices in the training of military specialists for the Armed Forces of Ukraine, taking into account national achievements.

Conclusions and prospects for further research:

1. A characteristic distinguishing feature of the functioning of the military education system at the present stage is that it acts both as an object and as a subject of reforming the Armed Forces of Ukraine and the defense forces as a whole. It is the high quality of training of military personnel that is an important condition for the timeliness, completeness, and effectiveness of the implementation of defense reform measures in Ukraine.

2. The most significant measures to bring Ukraine's military education system closer to Euro-Atlantic standards are:

transition to a three-stage education system (at the tactical, operational and strategic levels);

the introduction of the "school of defense management" and the "school of leadership" as components of the professionalization of education;

revision of qualification requirements and staffing categories in military posts of officers taking into account educational degrees and levels of military education;

reviewing the content of education and training, introducing NATO procedures and standards into the educational process;

drastic improvement in the training of sergeants.

Key words: military reform; military education; levels of military education. 